\title{
An EST database from saffron stigmas
}

\section{Nunzio D'Agostino ${ }^{1}$, Daniele Pizzichini ${ }^{2}$, Maria Luisa Chiusano ${ }^{1}$ and Giovanni Giuliano*2}

\author{
Address: ${ }^{1}$ Department of Soil, Plant, Environmental and Animal Production Sciences, University of Naples Federico II, via Università 100 - 80055 \\ Portici (NA), Italy and 2ENEA, Casaccia Research Center, PO Box 2400, Roma 00100AD, Italy \\ Email: Nunzio D'Agostino - nunzio.dagostino@gmail.com; Daniele Pizzichini - daniele.pizzichini@casaccia.enea.it; Maria \\ Luisa Chiusano - chiusano@unina.it; Giovanni Giuliano* - giuliano@casaccia.enea.it \\ * Corresponding author
}

Published: 9 October 2007

BMC Plant Biology 2007, 7:53 doi:10.1 186/147|-2229-7-53
Received: 29 April 2007

Accepted: 9 October 2007

This article is available from: http://www.biomedcentral.com/I47/-2229/7/53

(C) 2007 D'Agostino et al; licensee BioMed Central Ltd.

This is an Open Access article distributed under the terms of the Creative Commons Attribution License (http://creativecommons.org/licenses/by/2.0), which permits unrestricted use, distribution, and reproduction in any medium, provided the original work is properly cited.

\begin{abstract}
Background: Saffron (Crocus sativus L., Iridaceae) flowers have been used as a spice and medicinal plant ever since the Greek-Minoan civilization. The edible part - the stigmas - are commonly considered the most expensive spice in the world and are the site of a peculiar secondary metabolism, responsible for the characteristic color and flavor of saffron.

Results: We produced 6,603 high quality Expressed Sequence Tags (ESTs) from a saffron stigma cDNA library. This collection is accessible and searchable through the Saffron Genes database http:/ /www.saffrongenes.org. The ESTs have been grouped into I,893 Clusters, each corresponding to a different expressed gene, and annotated. The complete set of raw EST sequences, as well as of their electopherograms, are maintained in the database, allowing users to investigate sequence qualities and EST structural features (vector contamination, repeat regions). The saffron stigma transcriptome contains a series of interesting sequences (putative sex determination genes, lipid and carotenoid metabolism enzymes, transcription factors).
\end{abstract}

Conclusion: The Saffron Genes database represents the first reference collection for the genomics of Iridaceae, for the molecular biology of stigma biogenesis, as well as for the metabolic pathways underlying saffron secondary metabolism.

\section{Background}

Saffron (Crocus sativus L.) is a triploid, sterile plant, probably derived from the wild species Crocus cartwrightianus. It has been propagated and used as a spice and medicinal plant in the Mediterranean area for thousands of years [1]. The domestication of saffron probably occurred in the Greek-Minoan civilization between 3,000 and 1,600 B.C. A fresco depicting saffron gatherers, dating back to 1,600 B.C. has been unearthed on the island of Santorini, Greece.
Saffron is commonly considered the most expensive spice on earth. Nowadays, the main producing countries are Iran, Greece, Spain, Italy, and India (Kashmir). Apart from the commercial and historical aspects, several other characteristics make saffron an interesting biological system: the spice is derived from the stigmas of the flower (Figure $1 \mathrm{~A})$, which are harvested manually and subjected to desiccation. The main colors of saffron, crocetin and crocetin glycosides, and the main flavors, picrocrocin and safranal, are derived from the oxidative cleavage of the carotenoid, zeaxanthin [2,3] (Figure 1B). Saffron belongs to the Iri- 


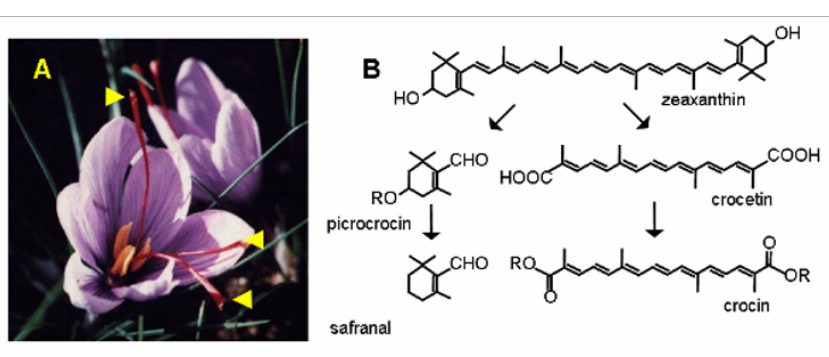

Figure I

The saffron spice. A. Crocus flowers. Arrowheads point to the stigmas, which, harvested and desiccated, constitute the saffron spice. B. Biosynthetic pathway of the main saffron color (crocin) and flavors (picrocrocin and safranal) (from [2], modified).

daceae (Liliales, Monocots) with poorly characterized genomes of relatively large size.

The characterization of the transcriptome of saffron stigmas is likely to shed light on several important biological phenomena: the molecular basis of flavor and color biogenesis in spices, the biology of the gynoecium, and the genomic organization of Iridaceae. For these reasons, we have undertaken the sequencing and bioinformatics characterization of Expressed Sequence Tags (ESTs) from saffron stigmas.

\section{Results and discussion Sequencing and assembly}

An oriented cDNA library from mature saffron stigmas in lambda Uni-ZAP [2] was kindly provided by Prof. Bilal Camara, University of Strasbourg. The library was subjected to automated excision, and the cDNA inserts were subjected to PCR amplification and sequenced from the 5' end.

9,769 electropherograms were analyzed with the Phred program [4]. Low quality sequences were removed from the $5^{\prime}$ and 3 ' ends, and the sequences were further processed to remove vector contaminations and to mask low complexity and/or repeat sub-sequences. This process reduced the original dataset to 6,603 high-quality sequences longer than 60 nucleotides. Only 6,202 EST fragments whose length is greater than or equal to 100 nucleotides were considered for the submission to the NCBI dbEST division. They are accessible under the accession numbers from EX142501 to EX148702.

The EST dataset was subjected to a clustering/assembling procedure [5], in order to group ESTs putatively derived from the same gene and to generate a tentative consensus sequence (TC) per putative transcript. The total number of clusters generated are 1,893. Each cluster should corre- spond to a unique gene, i.e. it represents a gene index. 1,376 clusters are made up of a single EST and are therefore classified as singletons. The remaining 517 clusters are made up of 5,324 ESTs, assembled into 534 TCs (Table 1). In 11 clusters, ESTs are assembled so that multiple TCs are defined (ranging from 2 to 6). Multiple TCs in a cluster have common regions of high similarity that may be due to possible alternative transcripts, to paralogy or to domain sharing. The GC content distribution in the dataset is reported in Figure 2. The average GC content is around $44 \%$.

\section{The database and the web interface}

The dataset was used to construct the Saffron Genes database [6]. The database architecture consists of a main MySQL relational database where all the data generated are deposited, and two satellite databases myGO and myKEGG. A user-friendly web interface is created using HTML and PHP scripts. A pre-defined query system supports data retrieval; HTML-tree graphical display is implemented to browse enzyme classes and metabolic pathways. Transcripts, which correspond to criteria defined by the user, can be mapped on-the-fly onto the KEGG metabolic maps, which are accessible as GIF images [7]. The electropherograms of the single ESTs can be downloaded to re-check sequence quality.

\section{Automated functional annotation}

In order to assign a preliminary function to each transcript, the TCs and singletons were compared using BLASTX to the UniProtKB/Swiss-Prot database. Of 1,910 transcripts, 1,158 (60.6\%) have no hits, while the remaining 752 (39.4\%) have at least one significant match in the protein database. Within this latter set, 131 (6.9\%) are described as hypothetical, unknown or expressed proteins thus not confirming an effective functional role of the transcript product.

Gene Ontology terms were assigned automatically to those 157 transcripts matching a protein in the UniProtKB/Swiss-Prot database whose accession numbers are present into the satellite database myGO (see Methods). In many cases, multiple gene ontology terms could be

Table I: Assembly statistics

\begin{tabular}{lll}
\hline Singleton ESTs & N. of sequences & 1,376 \\
& $\begin{array}{l}\text { Avg. EST length (nt) } \\
\text { Nucleotides masked }\end{array}$ & 239 \\
& & $10.2 \%$ \\
ESTs in contigs & N. of sequences & 5,324 \\
& Avg. EST length (nt) & 427 \\
& Nucleotides masked & $2.4 \%$ \\
Contigs & N. of contigs & 534 \\
& Avg. length (nt) & 552 \\
\end{tabular}




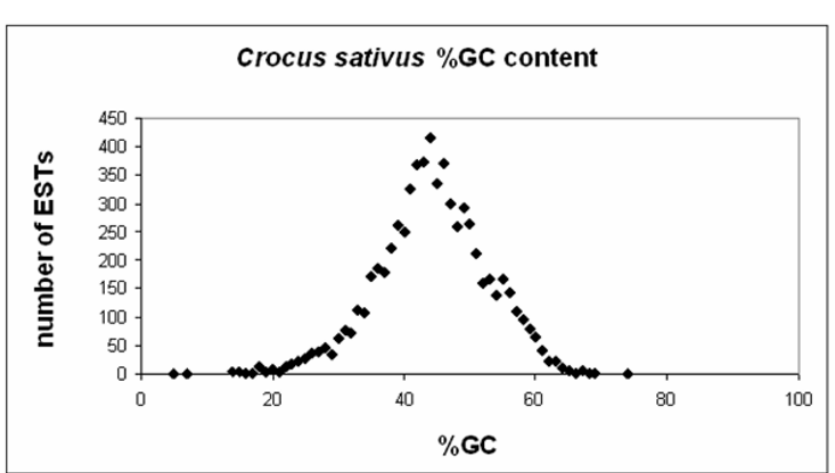

Figure 2

GC content distribution. The number of ESTs is plotted against their GC content. The average GC content is $44.3 \%$.

assigned to the same transcript, resulting in 210 assignments to the molecular function, 944 to the biological process and finally 2,192 to the cellular component class. To give a broad overview of the ontology content, the entire set of the ontologies was mapped onto the plant GO Slims terms. In the molecular function ontology class, the most represented terms describe catalytic (33.3\%) and hydrolase activity $(20.0 \%)$ (Figure $3 \mathrm{~A})$. The remaining categories are less represented. Considering the biological process class, the vast majority of the GO assignments corresponds to the more general transport category ( $78.8 \%)$ (Figure 3B). Finally, for the cellular component class the assignments were mainly given to the plastid (36\%), mitochondrion (33\%), and cytoplasmic membranebound vesicle (29\%) components (Figure 3C). 64 transcripts are associated to 46 distinct enzymes as they are classified and described into the ENZYME repository [8]. 35 out of the 46 enzymes had mappings to 55 KEGG biochemical pathways [9]. As we know, some enzymes can occur in more than one pathway; on the other hand there are 8 enzymes which only act in a single pathway, that were classified as pathway-specific (data not shown).

\section{Genes expressed in Crocus stigmas}

EST abundance in a contig can be indicative of the mRNA relative abundance in the stigma tissue. We identified the TCs that are composed of $\geq 20$ ESTs (Table 2). The most highly expressed TC, Cl000057:2 (547 ESTs), bears homology to short chain dehydrogenases (PF00106.12). This protein family comprises members involved in hormone biosynthesis, like the $A B A 2$ gene of Arabidopsis which catalyzes the conversion of xanthoxin into $\mathrm{ABA}$ aldehyde [10], or in sexual organ identity, like the TASSELSEED2 (TS2) gene of maize (Figure 4). TS2 is expressed in pistil primordia cells of maize, where it activates a cell death process eliminating these cells from male reproductive organs [11]. Biochemical studies suggest that the TS2 protein is a hydroxysteroid dehydrogenase [12]. It will be

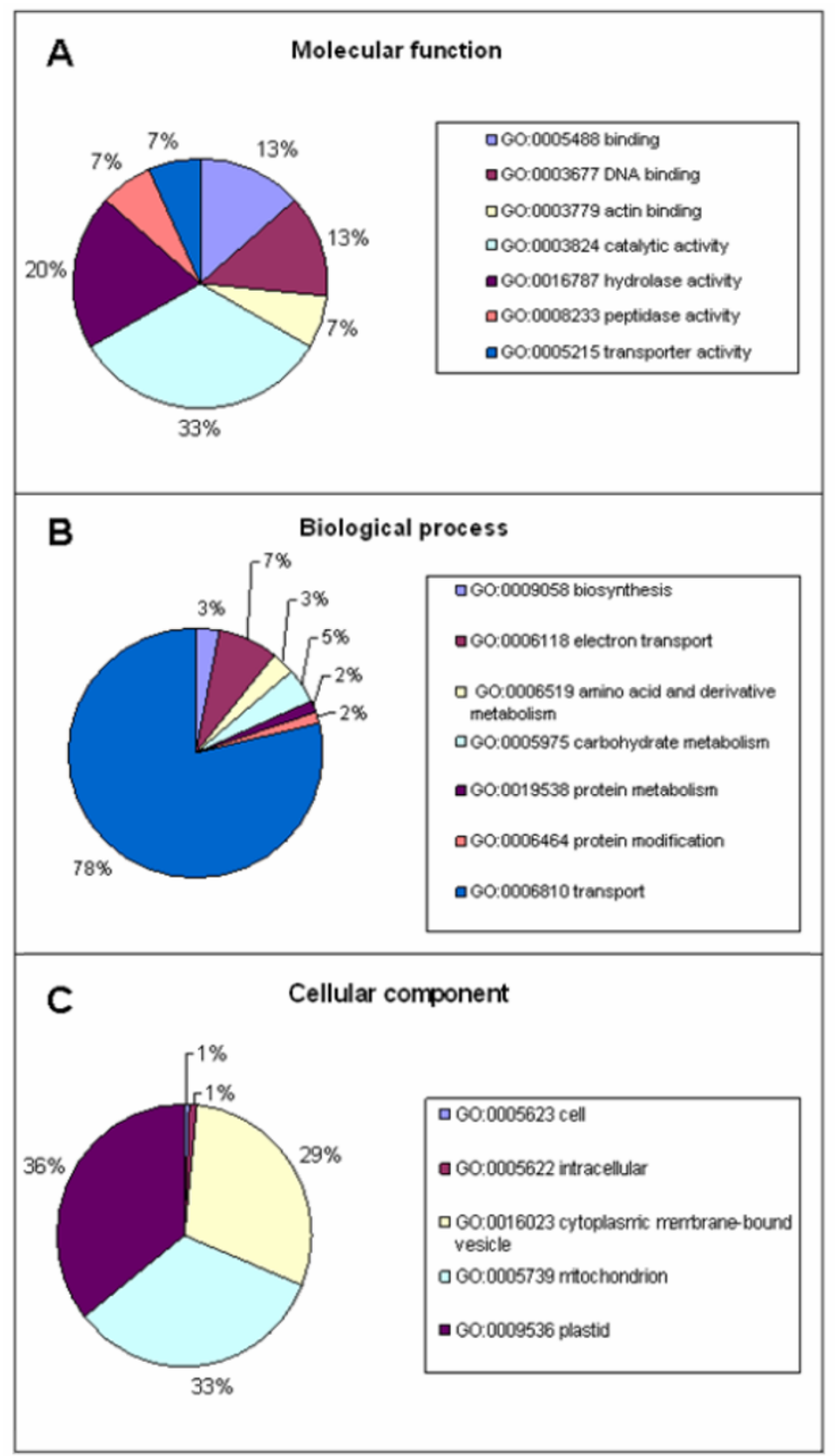

Figure 3

Assignments of Plant Gene Ontology terms to the Crocus putative transcripts. A. Molecular function $B$. Biological process C. Cellular component. For details, see Methods.

interesting to determine the function and substrate specificity of the saffron Cl000057:2 product.

A large number of Cytochrome P450 sequences are expressed in saffron stigmas, some of which at very high levels (Tables 2 and 3). Also, lipid metabolism seems to be very active, judging from the TCs encoding proteins involved in this process (Table 3 ).

Several TCs encode putative carotenoid metabolism enzymes (Table 3): Cl000944:1 encodes non-heme - $\beta$-car- 
Table 2: Highly expressed TCs

\begin{tabular}{|c|c|c|c|c|}
\hline Contig & \# ESTs & bp & BlastX annotation & e-value \\
\hline $\mathrm{Cl} 1000057: 2$ & 547 & 1242 & Q7XL00_ORYSA -OJ0003I5_02.17 protein & 0 \\
\hline $\mathrm{Cl} 1000837: 2$ & 122 & 1528 & Q8VZY2_MUSAC -Cytochrome P450-I & 0 \\
\hline Cl000799:2 & 114 & 711 & - & - \\
\hline $\mathrm{Cl001953:2}$ & 109 & 755 & O8082I_ARATH -Hypothetical protein At2g4|470 & I,00E-I6 \\
\hline $\mathrm{ClOOIII4:3}$ & 104 & 770 & HSPI3_ARATH - I8.2 kDa class I heat shock protein (HSP I8.2) & $\mathrm{I}, 00 \mathrm{E}-32$ \\
\hline Cl000299:I & 104 & 570 & Q9XHD5_IPOBA -BI2D protein & $2,00 \mathrm{E}-32$ \\
\hline Cl000870:I & 94 & 592 & Q6ZX06_ORYSA -Lipid transfer protein & $3,00 E-26$ \\
\hline Cl00I582:I & 61 & 600 & - & - \\
\hline Cl000209:I & 61 & 1071 & Q5GIM8_9POTV -Polyprotein (Fragment) & 0 \\
\hline Cl00II73:I & 56 & 785 & Q6H452_ORYSA -Putative monoglyceride lipase & 0 \\
\hline Cl000220:I & 55 & 831 & Q94HY3_ORYSA -Putative gamma-lyase & 0 \\
\hline Cl000348:I & 54 & 955 & Q9AVB7_9LILI -LhMyb protein & 0 \\
\hline $\mathrm{Cl} 001319: 1$ & 47 & 460 & Q8RVT5_PANGI -Acyl-CoA-binding protein & $\mathrm{I}, 00 \mathrm{E}-35$ \\
\hline Cl00I05I:I & 45 & 665 & Q8H293_ANACO -Cytochrome b5 & 0 \\
\hline Cl000246:I & 45 & 537 & - & - \\
\hline Cl000336:I & 44 & 685 & GPAT6_ARATH -Glycerol-3-phosphate acyltransferase 6 (EC 2.3.I.I5) & 0 \\
\hline Cl000468:2 & 42 & 1021 & Q70SZ8_9ASPA -Carboxyl methyltransferase & 0 \\
\hline Cl000482:I & 38 & 730 & Q84P95_ORYSA -Disulfide isomerase & 0 \\
\hline Cl000982:I & 38 & 230 & - & - \\
\hline Cl001040:I & 37 & 734 & Q8GZR6_LYCES -GcpE & 0 \\
\hline Cl00I329:I & 36 & 384 & Q4LEZ4_ASPOF -MADS-box transcription factor & I,00E-29 \\
\hline Cl00I8I5:I & 34 & 992 & BGAL_ASPOF -Beta-galactosidase precursor (EC 3.2.I.23) (Lactase) & 0 \\
\hline Cl000II3:I & 33 & 634 & Q6VAB3_STERE -UDP-glycosyltransferase 85A8 & $9,00 \mathrm{E}-16$ \\
\hline Cl000687:I & 33 & 782 & Q9XGS6_PRUDU -Cytosolic class II low molecular weight heat shock protein & 0 \\
\hline Cl000887:I & 33 & 802 & Q9FVZ7_ORYSA -Putative steroid membrane binding protein & 0 \\
\hline Cl00I463:I & 32 & 605 & Q9FE65_ARATH -60S ribosomal protein L34, putative & 0 \\
\hline Cl000932:I & 32 & 974 & Q652L6_ORYSA -Putative monodehydroascorbate reductase & 0 \\
\hline $\mathrm{Cl0018I2:I}$ & 30 & 554 & Q42338_ARATH -BI2D-like protein & $5,00 \mathrm{E}-32$ \\
\hline Cl00II34:I & 29 & 569 & Q8W453_ARATH -Hypothetical protein (DIRI protein) (At5g48485) & $7,00 \mathrm{E}-14$ \\
\hline Cl001906:I & 28 & 602 & Q4TESI_TETNG -Chromosome undetermined SCAF5I57 & $9,00 \mathrm{E}-07$ \\
\hline Cl001988:I & 25 & 1446 & Q8VX49_WHEAT -Cytochrome P450 reductase (EC I.6.2.4) & 0 \\
\hline Cl001107:1 & 24 & 783 & Q9SGA5_ARATH -FIC9.14 protein (At3g02070) & 0 \\
\hline Cl00I447:I & 24 & 453 & Q5VS45_ORYSA -Hypothetical protein P0425F02.23 & $1,00 \mathrm{E}-\mathrm{I} 2$ \\
\hline Cl0005I5:I & 24 & 506 & Q6ZCF3_ORYSA -Putative copper chaperone & $8,00 \mathrm{E}-15$ \\
\hline Cl000762:I & 24 & 247 & - & - \\
\hline $\mathrm{Cl} 1001114: 2$ & 23 & 748 & HSPI3_ARATH - I8.2 kDa class I heat shock protein (HSP I8.2) & $\mathrm{I}, 00 \mathrm{E}-32$ \\
\hline Cl00I894:I & 23 & 312 & - & - \\
\hline Cl000057:I & 23 & 740 & TRXHI_ARATH -Thioredoxin H-type I (TRX-H-I) & $\mathrm{I}, 00 \mathrm{E}-36$ \\
\hline $\mathrm{Cl} 100 \mathrm{I} 263: \mathrm{I}$ & 22 & 667 & Q9XH76_ARATH -Zinc finger protein-like (PMZ) & 0 \\
\hline Cl00I0I0:I & 21 & 1066 & Q8H2A7_ANACO -PFEI8 protein (Fragment) & 0 \\
\hline Cl000300:I & 21 & 506 & Q93WW3_NARPS -Metallothionein-like protein type 2 & $6,00 \mathrm{E}-12$ \\
\hline $\mathrm{Cl} 1000057: 3$ & 21 & 183 & - & - \\
\hline $\mathrm{Cl} 1000885: 2$ & 21 & 753 & Q41067_PINSY -Polyubiquitin & 0 \\
\hline Cl00I397:I & 20 & 798 & Q9LSQ5_ARATH -I,4-benzoquinone reductase-like; & 0 \\
\hline Cl00I774:I & 20 & 457 & Q9SN96_ARATH -Hypothetical protein FI8LI5.I50 & $7,00 \mathrm{E}-19$ \\
\hline Cl000I85:I & 20 & 397 & Q84LB7_MALDO -Cysteine protease inhibitor cystatin (Fragment) & $2,00 \mathrm{E}-12$ \\
\hline Cl001935:I & 20 & 673 & SRPI9_ARATH -Signal recognition particle 19 kDa protein (SRPI9) & $4,00 \mathrm{E}-38$ \\
\hline Cl000333:I & 20 & 418 & Q7F6G0_ORYSA -Putative metallothionein-like protein & $6,00 \mathrm{E}-20$ \\
\hline Cl000594:I & 20 & 1145 & SUSI_TULGE -Sucrose synthase I (EC 2.4.I.13) & 0 \\
\hline
\end{tabular}

otene-hydroxylase, which is highly expressed in saffron stigmas [13]. Cl000627:1 encodes a putative glucosyltransferase, very similar to UGTCs2, which is able to glycosylate crocetin in vitro [3] (Figure 4). Cl001532:1 and Cl001032:1 also, encode putative isoprenoid GTases, one of which could represent the still missing enzyme responsible for the glycosylation of picrocrocin (Figure 1).
Cl001432:1 encodes a protein similar to plastid terminal oxidase, involved in phytoene desaturation [14], while EST cr36_B21 encodes a protein similar to fibrillin, which is a carotenoid-binding protein in pepper chromoplasts [15]. Cl000468 encodes a carboxyl methyltransferase very similar to the one catalyzing the synthesis of bixin [16] (Figure 4). This TC seems to encode a "short" form of the 
A
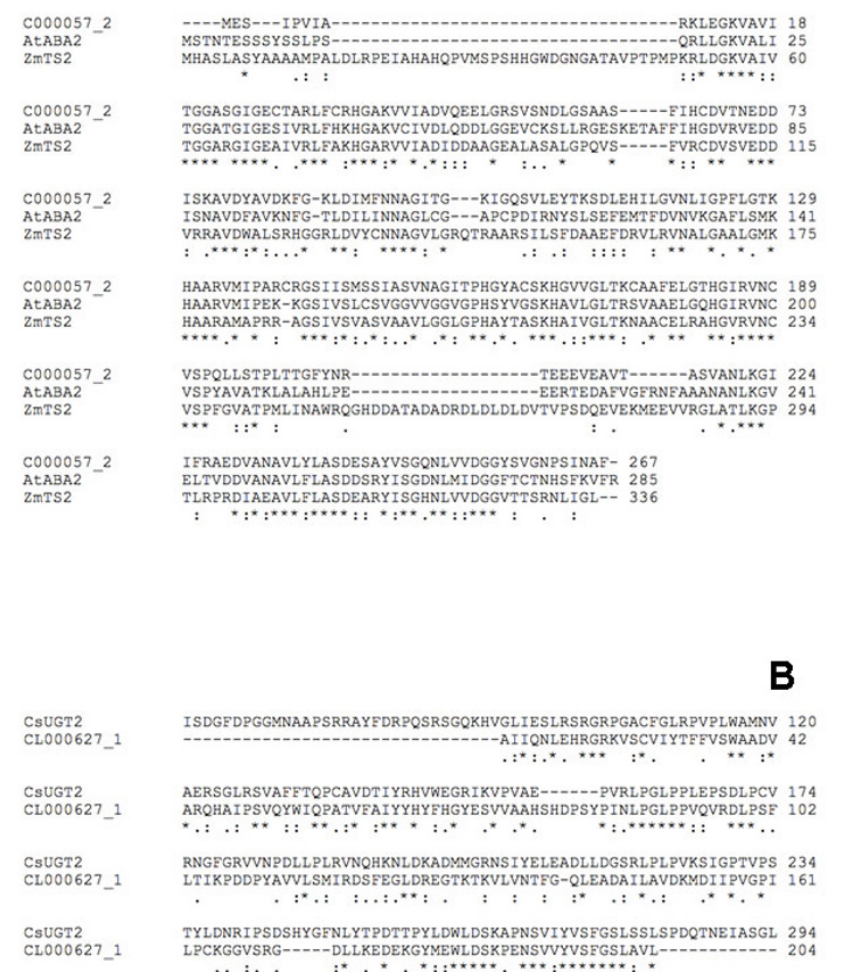

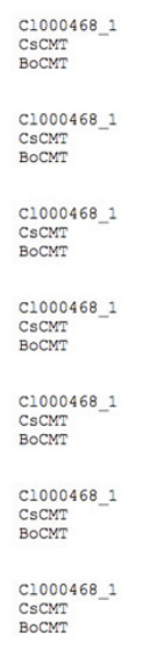

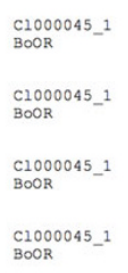

MAMNNVRQFLCMVGGDGETSYAKNSRI PEKATMR-TKPIVEEAIKEVYNSLQPKS-IVVA 5 -NCNVKLFLCNGGGDGETNYAKNSLIQDKAISR-TKPIVEEAIKEVYNSLNPKS-LVVA 56 GGRVRTICMTGGTGDASYAQNSLLQRKALSKITKPLTEAAIKELYYATIKPQTRLVIA 58 DLGCSSGPNTFLVISEIVEAIGDHCRKLGHNPPEIQYILNDLPGNDFNTLFDYSEKFKEK 118 DLGCSSGPNTFLVISEIVEAIGDHCRKLGHNPPEIQYILNDLPGNDENTLFDYSEKFKEK 116 DLGCSSGPNTFLAVSELVDAVGEFRKKATRNSPEIQTNLNDLPRNDENTLFRSVKFNQK 118 LKEVEEEVYPYYVGYPGSTYGRLFPQSSVHFTHSSYSTHWIS-LKEVEEEVYPYYVGYPGSFYGRLFPOSSVHFTHSSYSLHWL SQYPQGLKSDTGLPLNKRN 160 KKAVDEDYTY VSGVPSFYNRLFPSESTHFTHSSYARHNLSOVPKGRTNDAGLERNKGN 178

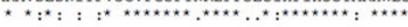

TYIAKSSPQTVAESYLKOFOVGLFSISHVKTLITRDGGPMTLIFFGKDRTKAPCGEISS 236

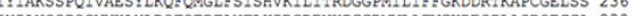
CFGLLADALNAMVLEGIMNEAKVEDFNLPIYAASMEEVVMTIVETIGLTIGLEVEVEIFETNW 206 VYNLLAMALSGLVAEGLLADSKVDQFNLPKYNPSPQETMPLVRKVGSFETAKLENHERQW 298 DPFDDSSDDDESAFDNFASGKNVVNCSIRAVVEPMFEKYFGEAIMDELFSRYAKNVAKHL 266 DPFDDSSDDDESAFDNFASGKNVVNCSIRAVVEPMFEKYFGEAIMDELFSRYAKNVAKHL 356 ESCPQDADGRTS-NALQSGQNVAQT-IRAVAEPALEKHFGDAIMEELFTRYAKLVAKHL 355 LGEKGKHVVEMMALRK---- 282 LGEKGKHVVFMMALRK---- 372 TAEKRKFVLNVMQLTKK
$\therefore * * *:::^{*} *$

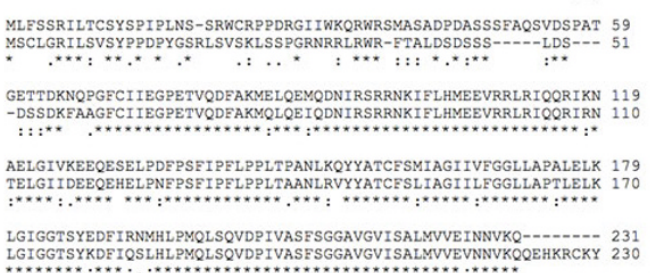
CIVEEOESELPDEPSETPFLPPLTPANLKOYYATCESMIAGIIVFGGLLAPALELK 179 GIGGTSYEDFIRNMHLPMOISOVDPTVASESGGAVGUISALMYVEINNVKQ-------- 231 LGIGGTSYKDFIQSLHLPMQLSQVDPIVASFSGGAVGVISALMVVEVNNVKQQEHKRCKY 230

\section{Figure 4}

ClustalW alignments of deduced protein sequences expressed in Crocus stigmas. A. Cl000057:2, aligned with short chain alcohol dehydrogenases: Arabidopsis ABA2 (GenBank acc. NP_175644) and maize TS2 (GenBank acc. P50I60). B.

Cl000627:I, aligned with Crocus crocetin Glycosyltrasferase 2 (GenBank acc. P50I60). C. Cl000468:I, aligned with Bixa and Crocus carboxyl methyltransferases (Genbank acc. CAD70I 90 and CAD70566) D. CI000045:I, aligned with cauliflower Or (GenBank acc. ABH07405).

annatto and crocus methyltransferases from GenBank, possibly derived from alternative splicing (Figure 4). Although a methyltransferase reaction has not been described in saffron stigmas, the biosynthesis of bixin and that of crocin share some features in common, since both pigments are derived from the oxidative cleavage of a carotenoid [17]. Finally, Cl000045:1 encodes a protein highly similar to the cauliflower Or gene product, a plastid-associated protein with a cysteine-rich DnaJ domain. A dominant $O r$ mutation induces $\beta$-carotene accumulation in cauliflower inflorescences, suggesting that $\mathrm{Or}$ is somehow involved in the control of chromoplast differentiation $[18,19]$.

Several TCs encode putative transcription factors (Table 3 ). The most abundantly expressed, Cl000348:1, encodes a Myb-like protein with high similarity to LhMyb (from Lilium, GenBank accession BAB40790) Myb8 (from Gerbera [20] - also showing similarity to Cl000348:2) and Myb305 (From Antirrhinium [21]). All three factors are highly expressed in flowers. Also highly expressed is
Cl001329:1, encoding a putative MADS box transcription factor. This protein shows high similarity to AODEF, a Bfunctional transcription factor from Asparagus expressed in stamens and inner tepals [22] and to LMADS1, a lily protein whose ectopic expression in dominant negative form causes an ap3-like phenotype in Arabidopsis [23].

Finally, several TCs - Cl000209:1 (61 ESTs) Cl000582:1 (18 ESTs) Cl001827:1 (5 ESTs) and Cl000731(2 ESTs) show similarity to potyviral sequences, indicating that the sequenced library likely derives from virus-infected tissue. Potyviruses like Iris Mild Mosaic Virus are known to infect Crocus [24]. The sequences of these TCs will prove useful for diagnostic and phytosanitary purposes.

\section{Conclusion}

The Saffron Genes database [6] has been designed to manage and to explore the EST collection from saffron stigmas, providing a reference for the expression pattern analysis in this tissue as well as a primary view of the genomic properties of this species, representative of Iri- 
Table 3: TCs grouped by putative function

\begin{tabular}{|c|c|c|c|c|}
\hline Contig & \# ESTs & bp & BlastX annotation & e-value \\
\hline \multicolumn{5}{|c|}{ Cyt. P450 } \\
\hline cr.saCl000837:2 & 122 & 1528 & Q8VZY2_MUSAC - Cytochrome P450-I & 0 \\
\hline cr.saCl00 I988:I & 25 & 1446 & Q8VX49_WHEAT - Cytochrome P450 reductase (EC I.6.2.4) & 0 \\
\hline cr.saCl000837:3 & 17 & 674 & Q8L5Q2_CICAR - Putative cytochrome P450 monooxygenase & $2 e-27$ \\
\hline cr.saCl0004|4:I & 5 & 752 & Q9AVMI_ASPOF - Cytochrome P450 & 0 \\
\hline cr.saCl000I50:I & 3 & 406 & Q9ATU9_LOLRI - Putative cytochrome P450 & $4 \mathrm{e}-17$ \\
\hline cr.saCl000I66:I & 3 & 710 & Q6EP96_ORYSA - Putative cytochrome P450 & $9 e-16$ \\
\hline cr.saCl00।887:I & 2 & 248 & Q6H5I6_ORYSA - Putative cytochrome P450 & 0.0004 \\
\hline cr.saCl000837:I & 2 & 600 & Q8VZY2_MUSAC - Cytochrome P450-I & $3 e-16$ \\
\hline crl3_OII & 1 & 360 & Q8S7S6_ORYSA - Cytochrome P450-like protein & $7 e-35$ \\
\hline cr2I_F05 & I & 448 & Q8S7S6_ORYSA - Cytochrome P450-like protein & $1.00053 e-42$ \\
\hline cr28_MI6 & 1 & 533 & Q6Z0U4_ORYSA - Putative cytochrome P450 reductase & 0 \\
\hline cr34_J15 & 1 & 509 & Q8S7S6_ORYSA - Cytochrome P450-like protein & 0 \\
\hline
\end{tabular}

Lipid metabolism

\begin{tabular}{|c|c|c|c|c|}
\hline cr.saCl000870:I & 94 & 592 & Q6ZX06_ORYSA - Lipid transfer protein & $3 e-26$ \\
\hline cr.saCl00I I73:I & 56 & 785 & Q6H452_ORYSA -Putative monoglyceride lipase & 0 \\
\hline cr.saCl000787:I & 10 & 743 & Q94GF2_ORYSA - Putative phospholipase & 0 \\
\hline cr.saCl001992:I & 5 & 637 & Q52RN7_LEOAR - Non-specific lipid transfer protein-like & $2 e-28$ \\
\hline cr.saCl001009:I & 5 & 667 & O04439_ALLPO - 3-ketoacyl carrier protein synthase III & 0 \\
\hline cr.saCl00 I749:I & 5 & 635 & Q9NCL8_DICDI - Phosphatidylinositol transfer protein I & $5 e-30$ \\
\hline cr.saCl000344:I & 5 & 704 & O49902_NICRU - I-phosphatidylinositol-4,5-bisphosphate phosphodiesterase & 0 \\
\hline cr.saCl0008I6:I & 2 & 677 & Q6K7T9_ORYSA - Peroxisomal fatty acid beta-oxidation multif. protein & 0 \\
\hline cr.saCl000294:I & 2 & 707 & Q84Z9I_ORYSA - Oxysterol-binding protein-like & 0 \\
\hline cr.saCl00074l:I & 2 & 734 & STAD_ORYSA - Acyl-(acyl-carrier-protein) desaturase, chloroplast precursor & 0 \\
\hline crl3_F23 & I & 350 & Q8S459_LYCES - Putative sphingolipid delta 4 desaturase DES-I & 0 \\
\hline crl5_P04 & I & 306 & GPX4_MESCR - Probable phospholipid hydroperoxide glutathione peroxidase & $5 e-16$ \\
\hline cr27_P08 & I & 74 & Q5N7U2_ORYSA - Phospholipid/glycerol acyltransferase-like protein & $4 \mathrm{e}-06$ \\
\hline cr35_MI7 & I & 437 & GPX4_MESCR - Probable phospholipid hydroperoxide glutathione peroxidase & le-24 \\
\hline
\end{tabular}

\section{Carotenoid metabolism}

\begin{tabular}{|c|c|c|c|c|}
\hline cr.saCl000944:I & 11 & 645 & Q8VXP2_9ASPA - Beta-carotene hydroxylase & $4 e-17$ \\
\hline cr.saCl00I432:I & 2 & 602 & Q9FZ04_CAPAN - Plastid terminal oxidase & 0 \\
\hline cr.saCl00I532:I & 7 & 420 & GT_CITUN - Limonoid UDP-glucosyltransferase & $2 \mathrm{e}-06$ \\
\hline cr.saCl00 I032:I & 2 & 426 & 5CD69_9MYRT - Monoterpene glucosyltransferase & $2 e-08$ \\
\hline cr.saCl000627:I & 2 & 611 & 69UF5_ORYSA - Putative anthocyanin 5-O-glucosyltransferase & 0 \\
\hline cr.saCl000468:2 & 42 & 1021 & Q70SZ8_9ASPA - Carboxyl methyltransferase & 0 \\
\hline cr.saCl000468:I & 6 & 767 & 70SZ8_9ASPA - Carboxyl methyltransferase & 0 \\
\hline cr9_02 & 1 & 69 & Q9FEC9_LYCES - Plastid quinol oxidase (Plastid terminal oxidase) & le-05 \\
\hline cr36_B2I & I & 706 & PAP2_ORYSA - Probable plastid-lipid associated protein 2, chloroplast precursor & 0 \\
\hline cr.saCl000045 & 14 & 746 & Q9FKF4_ARATH - Hypothetical protein At5g61670 & 0 \\
\hline
\end{tabular}

\section{Transcription factors}

\begin{tabular}{|c|c|c|c|c|}
\hline cr.saCl000348:I & 54 & 955 & Q9AVB7_9LILI - LhMyb protein & 0 \\
\hline cr.saCl00 I329:I & 36 & 384 & Q4LEZ4_ASPOF - MADS-box transcription factor & le-29 \\
\hline cr.saCl000348:2 & 6 & 669 & Q70RD2_GERHY - MYB8 protein & 0 \\
\hline cr.saCl0007|2:I & 6 & 714 & Q6Z8N9_ORYSA - Putative AT-hook DNA-binding protein & 0 \\
\hline cr.saCl000359:I & 5 & 593 & O82II5_ORYSA - Zinc finger protein & $5 e-19$ \\
\hline cr.saCl000502:I & 3 & 565 & ULTI_ARATH - Protein ULTRAPETALAI & $4 e-37$ \\
\hline cr.saCl000652:I & 2 & 537 & Q6ZG02_ORYSA - Putative DNA-binding protein WRKY2 & 0 \\
\hline crl7_JI5 & 1 & 567 & Q6Q6W8_9ASPA - Agamous MADS-box transcription factor la & 0 \\
\hline cr26_BI2 & I & 653 & Q8LAP4_ARATH - Similar to MYB-related DNA-binding protein & $2 e-23$ \\
\hline cr6_BI3 & i & 312 & Q9M7F3_MAIZE - LIM transcription factor homolog & 0 \\
\hline
\end{tabular}


daceae. The complete set of raw EST sequences, as well as of their electopherograms, are maintained in the database allowing users investigate on library qualities and on single EST structural features (vector contamination, repeat regions). Annotation is provided for single ESTs as well as for their assemblies (tentative consensus), to evaluate the consistency of the automated functional assignments. The putative transcripts determined to be associated to enzymes are organized into classes and can be viewed also in terms of enzyme assignments to metabolic pathways. This represents a straightforward way to investigate the properties of the stigma transriptome. As discussed above, this transcriptome contains a series of interesting sequences, whose function can now be tested using in vivo or in vitro approaches.

\section{Methods \\ EST sequencing}

An oriented cDNA library from mature saffron stigmas in lambda Uni-ZAP [2] was kindly provided by Prof. Bilal Camara, University of Strasbourg. The pBluescript phagemids contained in the phages were subjected to in vivo excision using the ExAssist helper phage and the SOLR strain according to the manufacturer's protocols (Stratagene Uni-ZAP manual) and plated on LB Agar plates with Ampicillin, IPTG and X-GAL. White colonies were picked by hand and grown overnight in LB 384-well plates in LB+Ampicillin. Approx. $1 \mathrm{uL}$ of each saturated culture was inoculated using a 384-pin tool (VP Scientific) in a $20-\mathrm{uL}$ PCR reaction containing $50 \mathrm{ng}$ each of primers T3 and T7 (Stratagene) and 0.5 U Taq Polymerase (GE Healthcare). The reactions, in 384-well format, were amplified using the following PCR cycle: denaturation step $\left(94^{\circ} \mathrm{C} 2^{\prime}\right)$, followed by 35 cycles of denaturation $\left(94^{\circ} \mathrm{C} 45^{\prime \prime}\right)$ annealing $\left(50^{\circ} \mathrm{C} 45^{\prime \prime}\right)$ and elongation $\left(72^{\circ} \mathrm{C}\right.$ $\left.2^{\prime}\right)$, followed by an elongation step $\left(72^{\circ} \mathrm{C} 10^{\prime}\right)$. Approx. $1 /$ 4 of the PCR reactions were checked by loading $2 \mathrm{~mL}$ on a $1 \%$ agarose gel, and only plates containing $>80 \%$ amplified, robust single bands were processed further. The PCR reactions were purified by gel filtration on 384-well deep-well PVDF plates (Corning cat. 3531). Each well was filled with $250 \mathrm{~mL}$ of resin (3.5\% Sephadex G-100, GE Healthcare) and the resin was packed by centrifugation at $3.000 \times \mathrm{g}$ for 5 '; after addition of $150 \mathrm{~mL}$ of resin, the plate was re-centrifuged as above; $10 \mathrm{~mL}$ of the PCR template were loaded in each well and the purified reaction was collected by centrifugation as above.

$3 \mathrm{~mL}$ of the PCR template were used for sequencing with the T3 primer in a final volume of $10 \mathrm{~mL}$ in 384-well format. The BigDye Terminator kit v 3.1 (Applied Biosystems) was used according to the manufacturer's instructions at a dilution of 1:16. The dye terminators were removed by gel filtration on 384-well deep-well PVDF plates (see above) using 6.5\% Sephadex G-50 fine
(GE Healthcare). The reactions were loaded on an ABI 3730 sequencer with $50-\mathrm{cm}$ capillaries.

\section{EST processing and contig assembly}

The electropherograms were analyzed using the pipeline ParPEST developed at the University of Naples [5]. Sequence base calls were performed using Phred [4] with a quality cutoff of 0.05 . Vector contaminations were identified using RepeatMasker [25] and NCBI's UniVec as filtering database. RepeatMasker and RepBase [26] are used for filtering and masking low complexity sub-sequences and interspersed repeats. EST clustering was made using PaCE [27] with default parameters. All the ESTs in a cluster are assembled into contigs using CAP3 [28] with an overlapping window of 60 nucleotides and a minimum score of 85.

\section{Functional annotation}

Raw EST data and contigs are compared using BLASTX against the UniProtKB/Swiss-Prot database [29]. The BLAST search is filtered setting an e-Value less equal than 0.001 . The association between the transcripts and the Gene Ontology terms occurs when the accession number of the protein subject is reported in the myGO database. All the GO terms related to each best BLAST hit were converted to the plant GO Slim terms using the map2slim.pl script, distributed as part of the go-perl package (version 0.04). The plant GO Slim file was downloaded from ... the Gene Ontology webpage [30]. The association between the transcripts and the Enzyme Commission (EC) numbers occurs if the EC is present in the description lines of each best BLAST hit. Transcripts, which are associated to EC numbers, are also linked to myKEGG and can be mapped onto the metabolic pathways.

\section{Multiple alignment generation}

ClustalW sequence alignment [31] was performed using the EBI web interface [32].

\section{Competing interests}

The authors declare that there are no competing interests.

\section{Authors' contributions}

GG planned and supervised the entire work. DP performed the sequencing. MLC planned and supervised the bioinformatics work which was implemented by NDA. GG and MLC wrote the paper. All authors read and approved the final manuscript.

\section{Acknowledgements}

Work supported by the Italian Ministry of Research (FIRB project) and the Italian Ministry of Agriculture (Agronanotech Project). We thank Prof. Bilal Camara for providing the cDNA library from saffron stigmas, Prof. Laura Spanò for supervision of DP's doctoral work and Francesca Cecchi for help with handling of electropherograms. This is DISSPAPA contribution $\mathrm{n}$. I5I. 


\section{References}

I. Fernandez JA: Biology, biotechnology and biomedicine of saffron. Recent Res Devel Plant Sci 2004, 2:127-159.

2. Bouvier F, Suire C, Mutterer J, Camara B: Oxidative remodeling of chromoplast carotenoids: Identification of the carotenoid dioxygenase CsCCD and CsZCD genes Involved in Crocus secondary metabolite biogenesis. Plant Cell 2003, I 5(I):47-62.

3. Moraga AR, Nohales PF, Perez JA, Gomez-Gomez L: Glucosylation of the saffron apocarotenoid crocetin by a glucosyltransferase isolated from Crocus sativus stigmas. Planta 2004, 219(6):955-966.

4. Ewing B, Hillier L, Wend MC, Green P: Base-calling of automated sequencer traces using phred. I. Accuracy assessment. Genome Res 1998, 8(3): |75-185.

5. D'Agostino N, Aversano M, Chiusano ML: ParPEST: a pipeline for EST data analysis based on parallel computing. BMC Bioinformatics 2005, 6(Suppl 4):S9.

6. [http://www.saffrongenes.org].

7. D'Agostino N, Aversano M, Frusciante L, Chiusano ML: TomatEST database: in silico exploitation of EST data to explore expression patterns in tomato species. Nucleic Acids Res 2007, 35(Database):D901-905.

8. Kanehisa $M$, Goto $S$, Hattori $M$, Aoki-Kinoshita KF, Itoh $M$, Kawashima S, Katayama T, Araki M, Hirakawa M: From genomics to chemical genomics: new developments in KEGG. Nucleic Acids Res 2006, 34(Database):D354-357.

9. Bairoch A: The ENZYME database in 2000. Nucleic Acids Res 2000, 28(I):304-305.

10. Gonzalez-Guzman M, Apostolova N, Belles JM, Barrero JM, Piqueras P, Ponce MR, Micol JL, Serrano R, Rodriguez PL: The short-chain alcohol dehydrogenase ABA2 catalyzes the conversion of xanthoxin to abscisic aldehyde. Plant Cell 2002, | 4(8): | 833-1846.

II. Calderon-Urrea A, Dellaporta SL: Cell death and cell protection genes determine the fate of pistils in maize. Development 1999 , | 26(3):435-44 I.

12. Wu X, Knapp S, Stamp A, Stammers DK, Jornvall H, Dellaporta SL, Oppermann U: Biochemical characterization of TASSELSEED 2 , an essential plant short-chain dehydrogenase/reductase with broad spectrum activities. Febs J 2007, 274(5): I I 72- I I 82

13. Castillo R, Fernandez JA, Gomez-Gomez L: Implications of Carotenoid Biosynthetic Genes in Apocarotenoid Formation during the Stigma Development of Crocus sativus and Its Closer Relatives. Plant Physiol 2005, I39(2):674-689.

14. Carol P, Kuntz M: A plastid terminal oxidase comes to light: implications for carotenoid biosynthesis and chlororespiration. Trends Plant Sci 200I, 6( I):31-36.

15. Deruere J, Romer S, d'Harlingue A, Backhaus RA, Kuntz M, Camara $B$ : Fibril assembly and carotenoid overaccumulation in chromoplasts: a model for supramolecular lipoprotein structures. Plant Cell 1994, 6(1): I 19-133

16. Bouvier F, Dogbo O, Camara B: Biosynthesis of the food and cosmetic plant pigment bixin (annatto). Science 2003, 300(5628):2089-2091.

17. Giuliano G, Rosati C, Bramley PM: To dye or not to dye: biochemistry of annatto unveiled. Trends Biotechnol 2003, 2 I (I 2):5|3-5I6.

18. Lu S, Van Eck J, Zhou X, Lopez AB, O'Halloran DM, Cosman KM Conlin BJ, Paolillo DJ, Garvin DF, Vrebalov J, Kochian LV, Kupper H, Earle ED, Cao J, Li L: The cauliflower Or gene encodes a Dna cysteine-rich domain-containing protein that mediates highlevels of beta\}-carotene accumulation. Plant Cell 2006, I 8:3594-3605.

19. Giuliano G, Diretto G: Of chromoplasts and chaperones. Trends Plant Sci 2007 in press.

20. Elomaa $P$, Uimari A, Mehto $M$, Albert VA, Laitinen RA, Teeri TH: Activation of anthocyanin biosynthesis in Gerbera hybrida (Asteraceae) suggests conserved protein-protein and protein-promoter interactions between the anciently diverged monocots and eudicots. Plant Physiol 2003, I33(4): 1831-1842.

21. Jackson D, Culianez-Macia F, Prescott AG, Roberts K, Martin C: Expression patterns of myb genes from Antirrhinum flowers. Plant Cell I99I, 3(2): I I5-125.

22. Park JH, Ishikawa $Y$, Yoshida R, Kanno A, Kameya T: Expression of AODEF, a B-functional MADS-box gene, in stamens and inner tepals of the dioecious species Asparagus officinalis $\mathbf{L}$. Plant Mol Biol 2003, 5 I (6):867-875.

23. Tzeng T-Y, Yang C-H: A MADS Box Gene from Lily (Lilium longiflorum) is Sufficient to Generate Dominant Negative Mutation by Interacting with PISTILLATA (PI) in Arabidopsis thaliana. Plant Cell Physiol 200I, 42(I0): I I 56-I I 68.

24. Navalinskijene $M$, Samuitiene $M$ : Viruses affecting some bulb and corm flower crops. Biologija 2001, 4:40-42.

25. [http://www.repeatmasker.org]

26. Jurka J: Repbase update: a database and an electronic journal of repetitive elements. Trends Genet 2000, I 6(9):4I 8-420.

27. Kalyanaraman A, Aluru S, Kothari S, Brendel V: Efficient clustering of large EST data sets on parallel computers. Nucleic Acids Res 2003, 3 I ( I I ):2963-2974.

28. Huang $X$, Madan A: CAP3: A DNA sequence assembly program. Genome Res 1999, 9(9):868-877.

29. Wu CH, Apweiler R, Bairoch A, Natale DA, Barker WC, Boeckmann B, Ferro S, Gasteiger E, Huang H, Lopez R, Magrane M, Martin M], Mazumder R, O'Donovan C, Redaschi N, Suzek B: The Universal Protein Resource (UniProt): an expanding universe of protein information. Nucleic Acids Res 2006, 34(Database):D|87-19|.

30. [http://www.geneontology.org/GO slims/goslim plant.obo]

31. Thompson JD, Higgins DG, Gibson TJ: CLUSTAL W: improving the sensitivity of progressive multiple sequence alignment through sequence weighting, position-specific gap penalties and weight matrix choice. Nucleic Acids Res 1994, 22(22):4673-4680.

32. [http://www.ebi.ac.uk/clustalw].
Publish with Bio Med Central and every scientist can read your work free of charge

"BioMed Central will be the most significant development for disseminating the results of biomedical research in our lifetime. "

Sir Paul Nurse, Cancer Research UK

Your research papers will be:

- available free of charge to the entire biomedical community

- peer reviewed and published immediately upon acceptance

- cited in PubMed and archived on PubMed Central

- yours - you keep the copyright
BioMedcentral 